\title{
Students' Loans by Financial Institutions: The way to reduce a burden for Government Funding to Higher Education in Tanzania
}

\author{
Veronica R. Nyahende \\ Department of Allocation and Disbursement, \\ Higher Education Students' Loans Board, \\ Dar es salaam, Tanzania
}

\begin{abstract}
Students' Loans are Government Loans extended to students in Higher Learning Institutions (HLIs), these Loans has to be repaid back on or after expiry of the grace period (HESLB, 2004). The purpose of this study is to assess the feasibility of engaging financial institutions to partner with the Government in financing higher education by addressing the following objectives:(i) to determine whether there is policy consideration for students' loans provision by financial institutions (ii) to examine the readiness of the students in the higher learning institutions to be financed by financial institutions (iii) to investigate the readiness of the financial institutions to provide loans to students of the higher learning institutions.

Data were collected through interviews, review of various documents and questionnaires in which 90 respondents were obtained 7 from financial institutions and 83 from higher learning institutions. Software package for statistical science (SPSS) and content analysis was used to analyse data, results of the analysis were presented in tabular form, frequency distribution table and the bar charts.

It was concluded that financial institutions in Tanzania does not have the policy to support students' loans provision hence they are not ready, students' in higher learning institutions are ready to be financed by financial institutions. The study recommends that the financial institutions in Tanzania should establish students' loans provision policy in their operations, universities or colleges to include policy which allows students to seek for alternative funding for their education other than the Government. Timely repayment among Students for smooth operation of the financial institutions. Education by HESLB on the need for alternative funding from financial institutions. Financial Institutions for Higher Education Financing.
\end{abstract}

Keywords: Students' Loans; Financial Institutions; Higher Learning Institutions; Government; feasibility. 


\subsection{Introduction}

\subsection{Students' Loans and the need for Alternative Funding}

Students' loans are given to students at lower interest rate to pay off their higher education related expenses such as tuition fees, books and stationeries expenses. These costs are payable to universities or university colleges (Nyahende, 2013). According to Chapman \& Mathias (2011) higher education is becoming important in the $21^{\text {st }}$ century to individuals and to the society at large for sake of economic prosperity, advancement of democracy as well as social justice. Therefore, the increase in demand for higher education has lead to the increase of the cost of higher education coupled with the inability of the Government to fully fund the rising cost of higher education due to its limited budget (Barr,2009). This situation has lead to a significant growth of students' loans schemes all over the world (Ziderman,2004).

In Tanzania, the students' loans scheme started to be operated in July, 2005 under the Higher Education Students' Loans Board (HESLB). HESLB is a body corporate established under the Act No.9 of 2004, (as amended) with the objective of assisting needy Tanzanian students, who secure admission in accredited higher Education institutions (HEIs). The Board has the task of advising the Government on matters relating to issuance of loans including seeking for alternative source of funding (HESLB, 2004).

Demand for higher Education in Tanzania has been increasing as evidenced by the increase in students' loans applications annually, this has led to the need for other source of finance to satisfy the increased demand.

\subsubsection{Mismatch between students' loans application and allocation at HESLB}

The increased enrolments in higher learning institutions, as a result of the increase in Secondary schools following the recently established Ward Secondary Schools and other Secondary schools, has lead to an increase in demand for higher education. The same was evidenced by the increase in the number students' loans applicants from 49,914 in year 2012/2013 to 55,033, and 62,359 in year 2013/2014 and 2014/2015 respectively. Table 1 shows the trend of the gap between students' loans applications and the allocated students or accepted students under students' loans scheme.

Table 1: Number of Loan Applications and Allocations

\begin{tabular}{|l|r|r|r|r|}
\hline \multicolumn{1}{|c|}{ Year } & $\begin{array}{c}\text { No. of } \\
\text { Applications }\end{array}$ & \multicolumn{1}{c|}{$\begin{array}{c}\text { No. of } \\
\text { Allocations }\end{array}$} & $\begin{array}{c}\text { (\%Allocated } \\
\text { students }\end{array}$ & $\begin{array}{c}\text { No. of Students } \\
\text { not allocated }\end{array}$ \\
\hline $2012 / 2013$ & 49,914 & 29,097 & $58 \%$ & 20,817 \\
\hline $2013 / 2014$ & 55,033 & 33,494 & $61 \%$ & 21,539 \\
\hline $2014 / 2015$ & 62,359 & 29,473 & $47 \%$ & 32,886 \\
\hline Total & $\mathbf{1 6 7 , 3 0 6}$ & $\mathbf{9 2 , 0 6 4}$ & $\mathbf{5 5 \%}$ & $\mathbf{7 5 , 2 4 2}$ \\
\hline
\end{tabular}

Source: HESLB (2015a) 


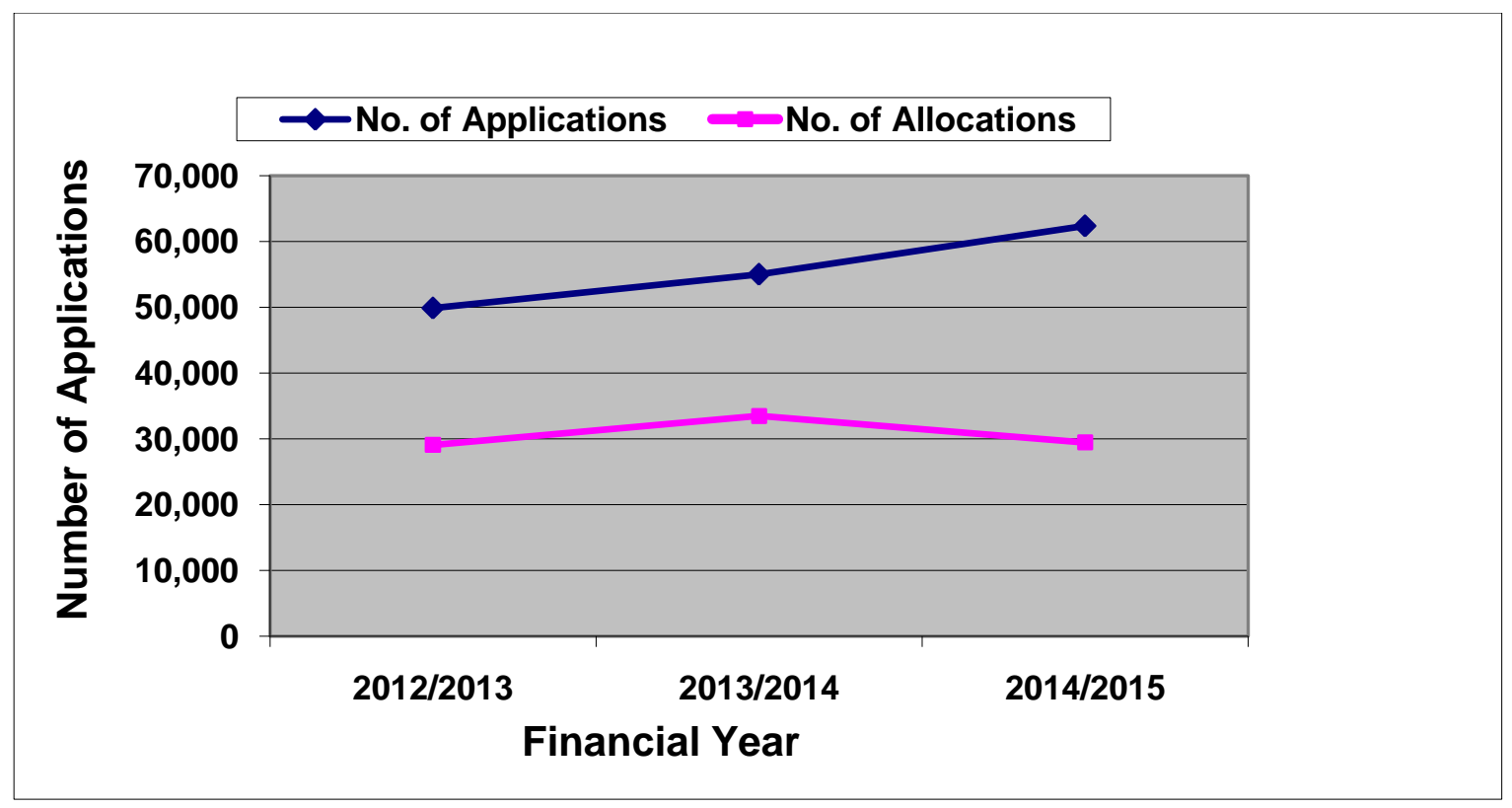

Figure 1: The Trend of Loan Applications vs Loans Allocations between 2012 and 2015

During the loan allocation process, after means testing some students are left out even though they are eligible and needy due to the limited amount of fund available. By partnering with financial institutions, these students will be given an option to seek for loans from financial institutions under special arrangements (HESLB, 2017). In that case HESLB is supposed to plays the role of negotiator on behalf of these applicants so that fair terms and conditions are set for mutual benefit of students (beneficiaries) and respective financial institutions.

According to Table 1, number of unallocated student or unaccepted students after means testing is increasing due to limited fund obtained from the Government. For three consecutive years, the Board (HESLB) has been receiving the same amount of money from the Government budget regardless of the increasing number of students' enrolments, hence the number of applicants offered loans has been diminishing annually (HESLB, 2015a).

With such trend, the number of students offered students' loans is expected to decrease continuously year after year. Unless strategic interventions are undertaken, financing of higher education in Tanzania will increasingly continue to be under critical financial constraints.

\subsection{Research Objectives}

\subsubsection{General Objective}

The general objective of this survey was to assess the feasibility of engaging financial institutions in financing higher education.

Specific Objectives

(i) To determine on whether there is policy consideration for students' loans provision by financial institutions 
(ii) To examine the readiness of the students in the higher learning institutions to be financed by financial institutions

(iii) To investigate the readiness of the financial institutions to provide loans to students of the higher learning institutions.

\subsubsection{Research Questions}

(i) Is there any policy consideration in the financial institutions regarding students' loans provision?

(ii) Are the students ready to be financed by the financial institutions?

(iii) Are the financial institutions ready to engage in students' loans provision?

\section{Methodology}

\subsection{Research Design}

According to Saunders, Lewis, \& Thornhill, (2007), research design is an outline of how the survey or an investigation will take place. Therefore, in this study cross- sectional research design was used in data collection, research questions were used to guide the study also frequency with which something occurred or relationship among variables were determined. Both desk and field research were applied

\subsection{Area of the Study, Population and Sample Selection}

This survey was conducted in the Dar es salaam city. the study was conducted in seven Universities in which 83 respondents consisting of management staff, dean of students, bursars, loan officers, and leaders of students' Organization were obtained. 4 Financial Institutions were visited too in which response were from Loan management team, Branch managers and loan officers. The Universities consists of the Dar es salaam (UDSM), Institute of Finance Management (IFM), Dar es salaam University College of Education (DUCE), College of Business Education (CBE), Dar es salaam Institute of Technology (DIT), Hurbert Kairuki Memorial University (HKMU) and Tumaini University Dar es salaam Campus (TUDARCO). Financial institutions visited were Tanzania Women Bank (TWB), Bank M, Tanzania Postal Bank (TPB) and National Bank of Commerce (NBC).

The researcher obtained the list of Universities from Tanzania Commission for Universities (TCU) database. List of financial institutions were also obtained from Bank of Tanzania (BOT) database.

Population of the study consists of Universities Management (22), Dean of students (7), Bursars (7), loans officers (7), leaders of the students' organizations, (40) Loan management team in the financial institutions (4), branch managers (1) and loan officer (2).

Given the researcher's knowledge and believe that the selected sample gives the desired answers, the use of stratified and purposive sampling was relevant in this phenomenon compared to other sampling techniques. The researcher needed respondents who are from management levels, leaders in students' 
organizations and leaders in loan management who understand the knowledge and the importance of engaging financial institutions in students' loans provision.

A total number of 100 questionnaires were distributed, 90 questionnaires (90\%) were properly filled and returned by the respondents.

\subsection{Sample Characteristics}

\section{Financial Institution (FI)}

Under the financial institutions, the characteristics of the respondents were categorised in term of the name of the financial institution, the ownership of the financial institutions, policy for students' loans considerations and consideration for gender parity. In order to understand the collected data, the descriptive analysis was conducted by the researcher. The detailed sample characteristic is as detailed in Table 2 to 4 .

\section{Name of the Financial Institution}

Questionnaires were evenly distributed among the four selected financial institutions. The findings indicate that more than $40 \%$ of the respondents were from NBC followed by TPB which is represented by more than $28 \%$ of the respondents. The remaining percentages was evenly distributed among the financial institutions. This distribution has been explained more in a percentage form using the bar chart under Figure 2.

Table 2: Name of the Financial Institution

\begin{tabular}{|r|r|r|r|r|}
\hline & Frequency & Percent & Valid Percent & $\begin{array}{c}\text { Cumulative } \\
\text { Percent }\end{array}$ \\
\hline TPB & 2 & 28.6 & 28.6 & 28.6 \\
NBC & 3 & 42.9 & 42.9 & 71.4 \\
Valid & 1 & 14.3 & 14.3 & 85.7 \\
BAB & 1 & 14.3 & 14.3 & 100.0 \\
M & 7 & 100.0 & 100.0 & \\
Total & & & \\
\hline
\end{tabular}

Source: Survey data (2017) 


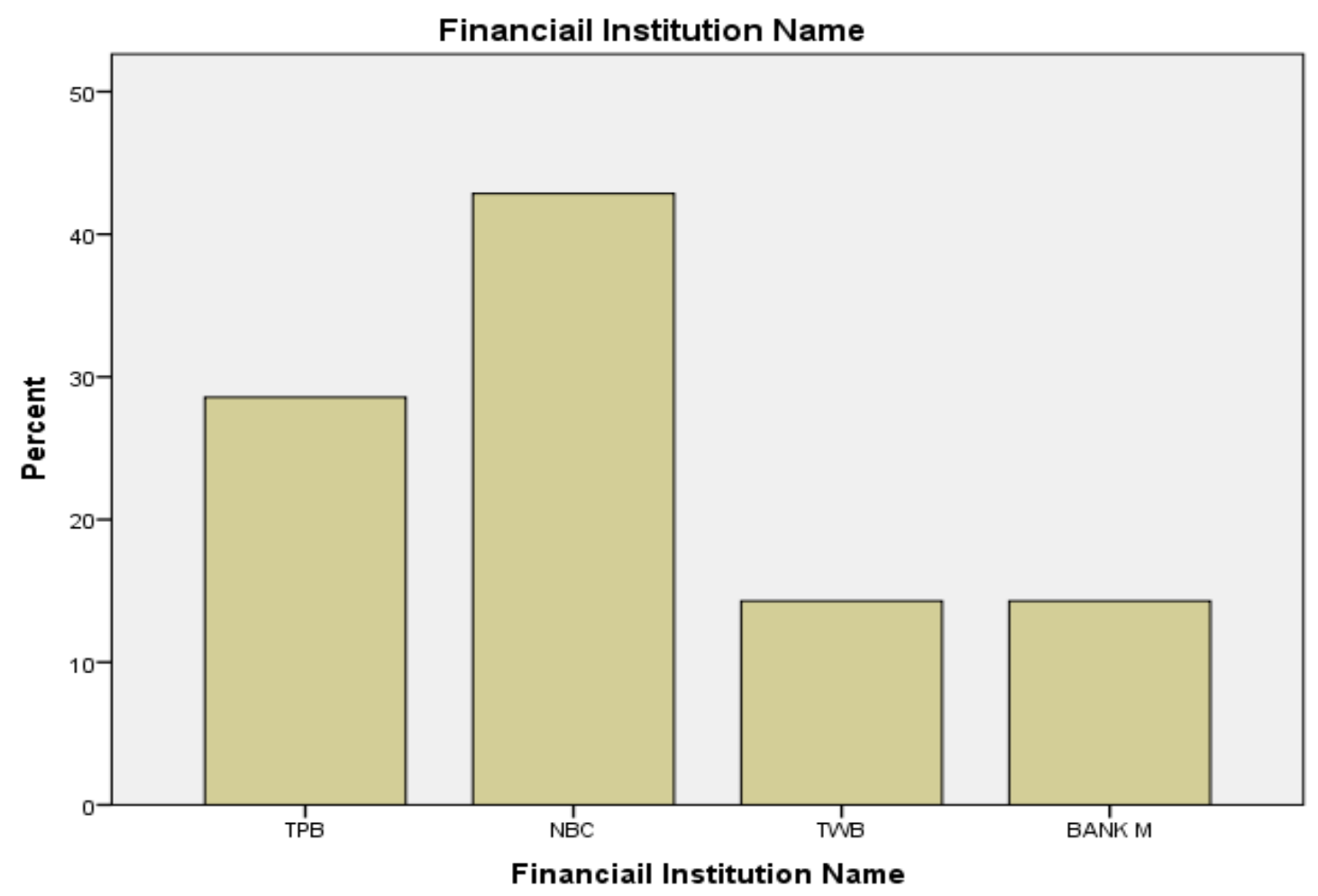

Figure 2: Financial Institution Name

\section{Institution ownership}

A Total four financial institutions were visited with different ownership ranging from private ownership, government ownership and the private- government (Share) ownership. The results indicate that more than $1 / 2$ of the financial institutions visited had the shared ownership between the government and the private, followed by $28 \%$ which are government owned, were by private ownership is formed by only $14 \%$. Researcher expected to find more financial institutions under the shared ownership between the government and private compared to government ownership this is due to the recent privatization move of the public institutions. This distribution has been explained more in a percentage form using the bar chart under Figure 3.

Table 3: Institution Ownership

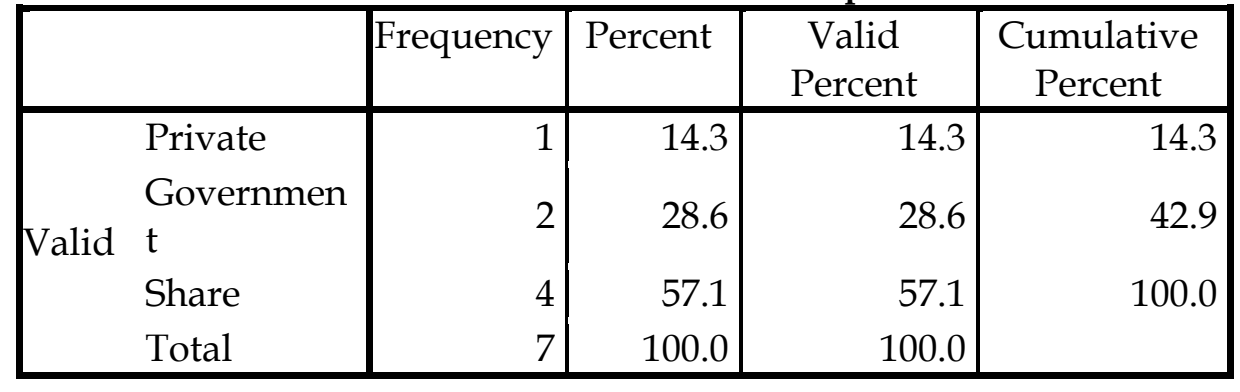

Source: Survey data (2017) 


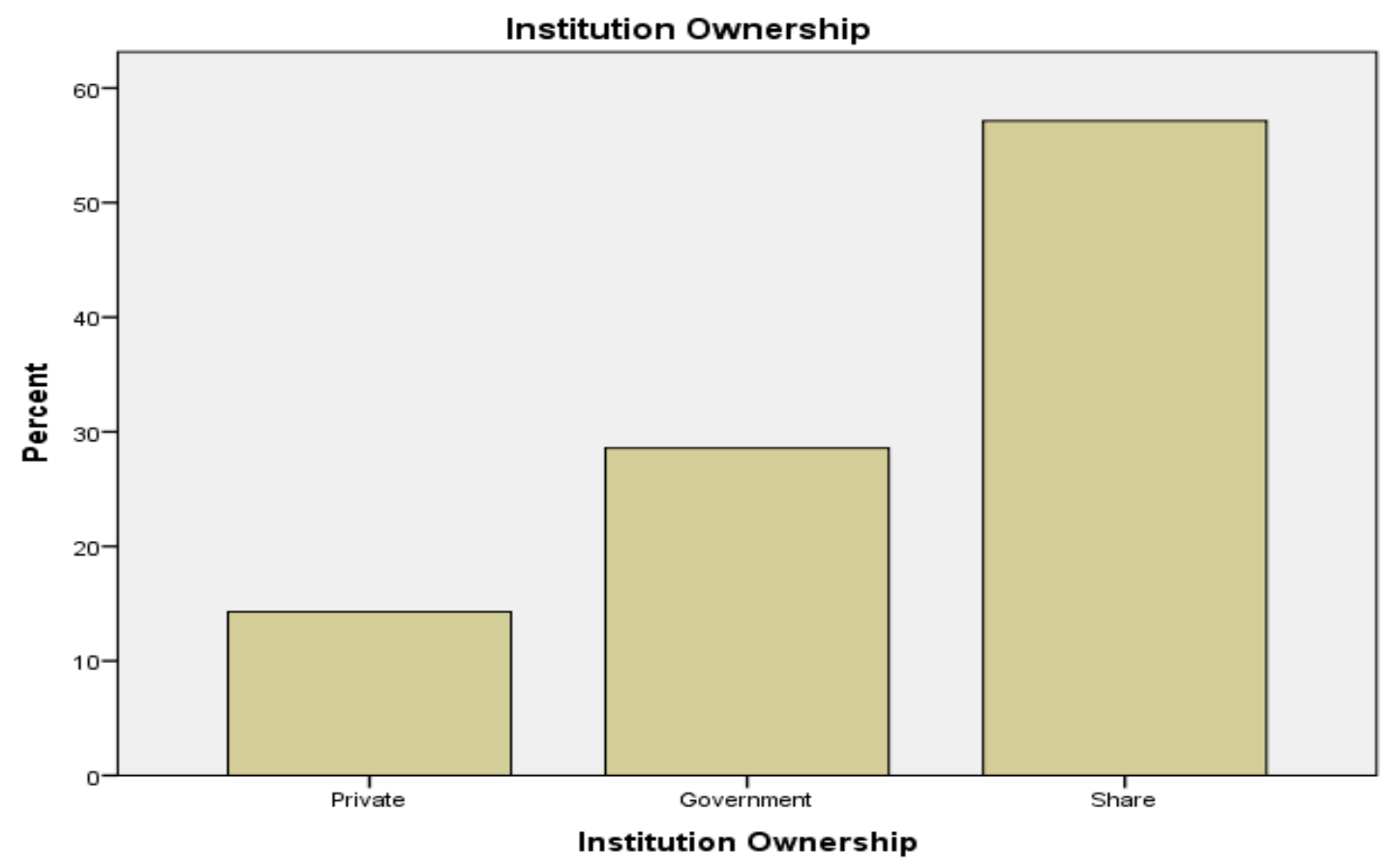

Figure 3: Institution Ownership

\section{Is There Any Policy for Student Loan Consideration?}

$80 \%$ of the respondents from financial institutions indicates that there is no policy regarding students' loans provision, while only $14 \%$ of the respondents indicates the presence of the policy considerations for students' loans provision. The results represent fairly the population because the researcher expected to find the same, as most of the financial institutions do give educational loans to employees in collaboration with the social security schemes which provide guarantee to the employees. This distribution has been explained more in a percentage form using the bar chart under Figure 4.

Table 4: Is There any policy For Student Loan consideration

\begin{tabular}{|c|c|c|c|c|c|}
\hline & Frequency & Percent & $\begin{array}{c}\text { Valid } \\
\text { Percent }\end{array}$ & $\begin{array}{c}\text { Cumulative } \\
\text { Percent }\end{array}$ \\
\hline \multirow{3}{*}{ Valid } & Yes & 1 & 14.3 & 14.3 & 14.3 \\
\hline & No & 6 & 85.7 & 85.7 & 100.0 \\
\hline & Total & 7 & 100.0 & 100.0 & \\
\hline
\end{tabular}

Source: Survey data (2017) 


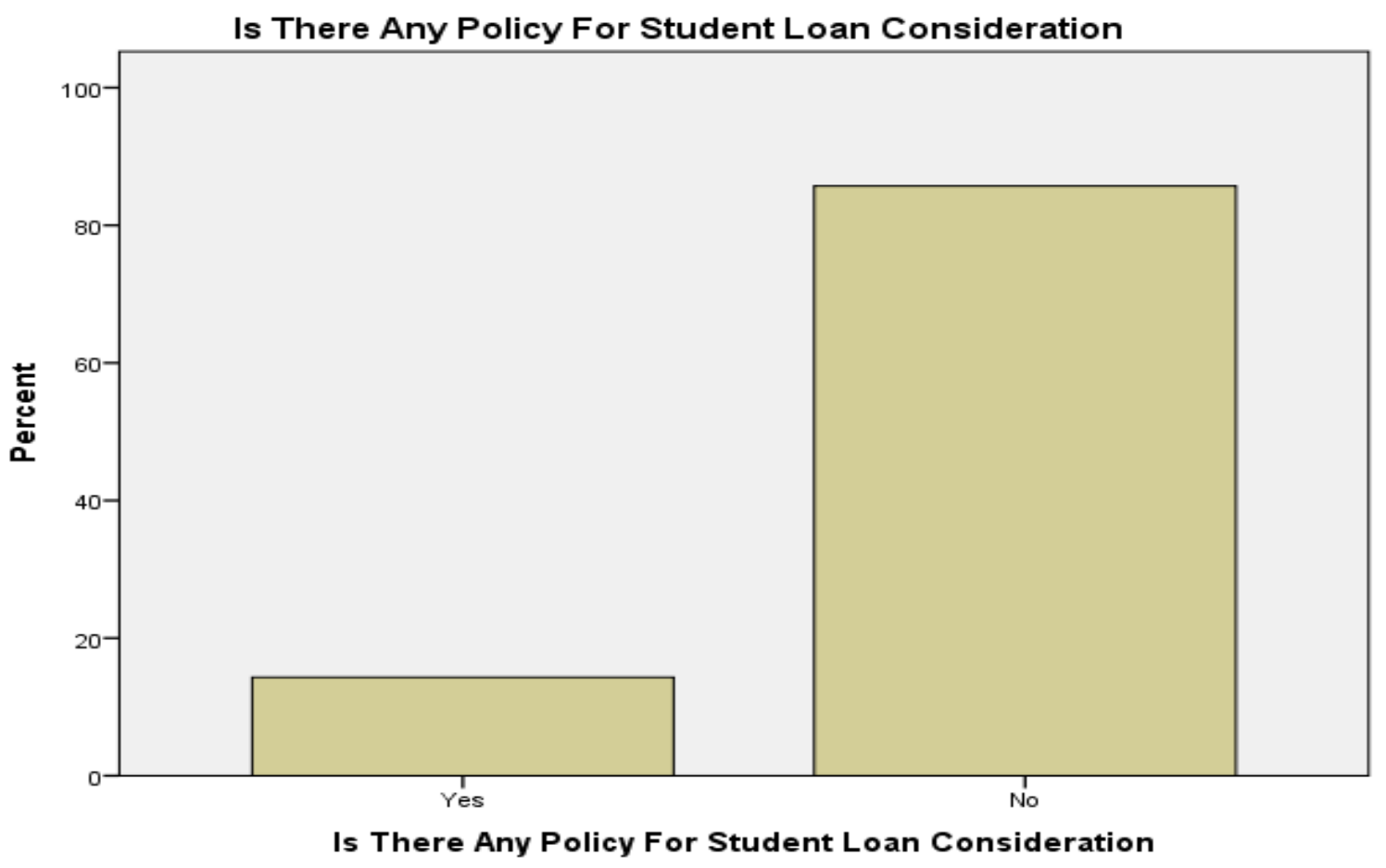

Figure 4: Is There any Policy for Student Loan Consideration

\section{Higher Learning Institutions}

Under the higher learning institutions the characteristics of the respondents were categorised in term of Name of the University College, Institution ownership, Enhancement of more loans to the needy students, University to surrender certificates of loans beneficiaries, Financial institutions will be allowed to request for additional securities, is there policies of considering students to seek loans from financial institutions,, should there be consideration for gender parity and financial institutions can use beneficiaries certificates as collateral. In order to understand the collected data, the descriptive analysis was conducted by the researcher. The detailed sample characteristic is as detailed in Table 5 to 11.

\section{University or College name}

A total of 83 respondents were obtained, respondents from UDSM forms 1/5 of the total population. The researcher expected UDSM to represent a greater portion of the population because of a big coverage it has a big number of management team, and leaders of the students' organization and it is the oldest compared to other universities in the country, respondents from IFM forms 18\% of the total population, also HKMU was expected by the researcher to form the least percentages of the respondents (at 5\%) because it has less coverage compared to other universities under the study). Therefore, there were fair university/college distribution, this is also explained more by the bar chart shown under Figure 5. 
Table 5: University/College

\begin{tabular}{|l|r|r|r|r|}
\hline & Frequency & Percent & $\begin{array}{c}\text { Valid } \\
\text { Percent }\end{array}$ & $\begin{array}{c}\text { Cumulative } \\
\text { Percent }\end{array}$ \\
\hline IFM & 15 & 18.1 & 18.1 & 18.1 \\
CBE & 14 & 16.9 & 16.9 & 34.9 \\
DIT & 10 & 12.0 & 12.0 & 47.0 \\
UDSM & 17 & 20.5 & 20.5 & 67.5 \\
Valid HKMU & 4 & 4.8 & 4.8 & 72.3 \\
DUCE & 14 & 16.9 & 16.9 & 89.2 \\
TUDARC & 9 & 10.8 & 10.8 & 100.0 \\
O & 83 & 100.0 & 100.0 & \\
Total & & & \\
\hline
\end{tabular}

Source: Survey data (2017)

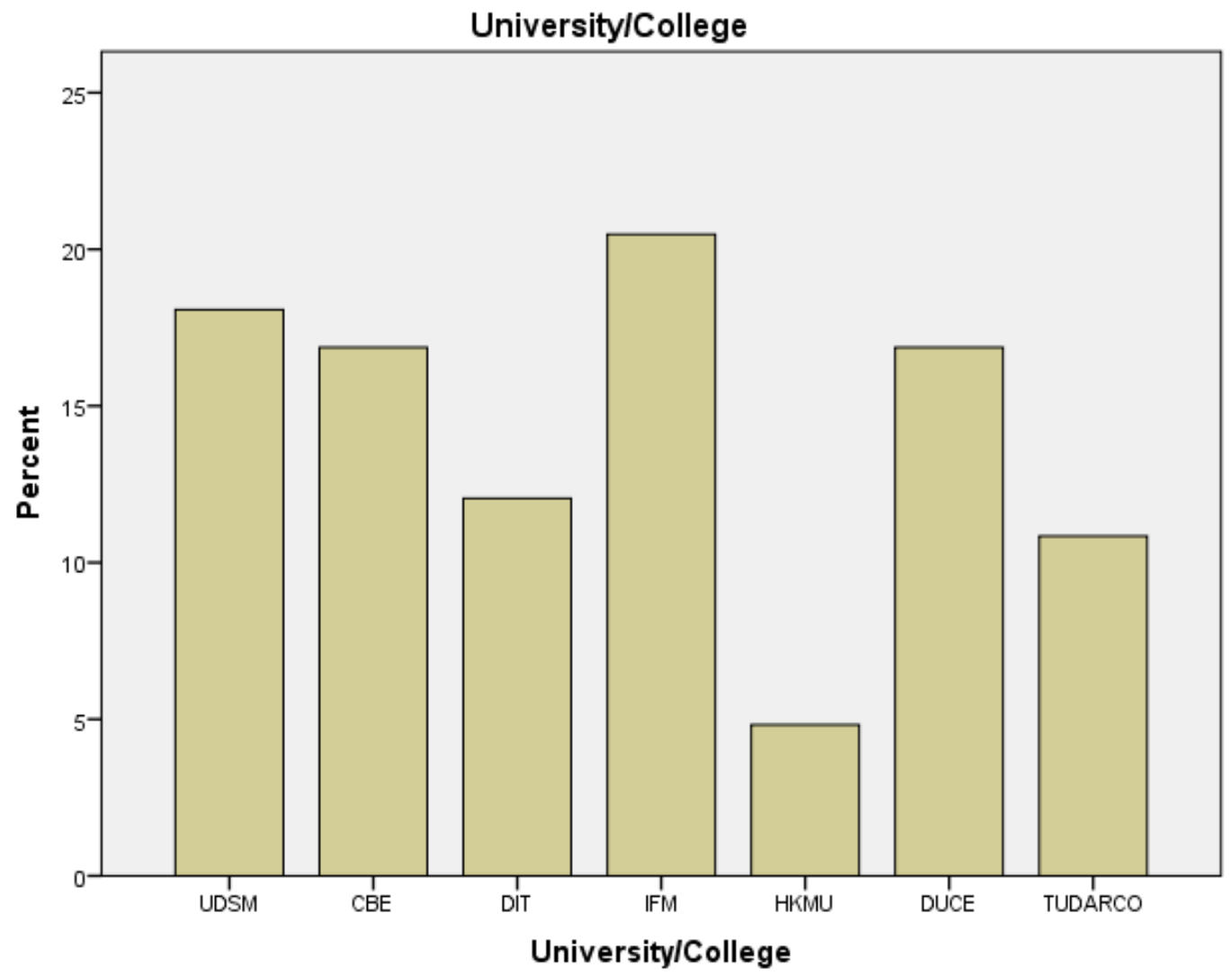

Figure 5: University or College 


\section{Institution Ownership (College/University)}

Results of the respondents from Universities/Colleges presented indicates that more than $80 \%$ of the respondents were from universities or colleges owned by the government, while only $15 \%$ of the respondents were from universities or college which are privately owned. These results were expected by the researcher because the country has more public universities compared to private universities. Also, students from low income brackets who are more interested in students' loans are found in public universities. Therefore, this implies that there was a fair institution ownership distribution among the respondents, the population was represented as anticipated. This distribution is explained more by the bar chart shown under Figure 6 .

Table 6: Institution Ownership

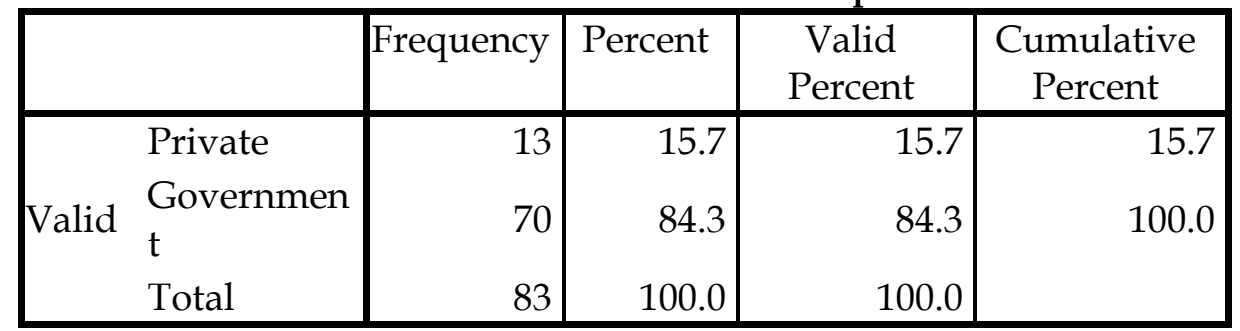

Source: Survey data (2017)

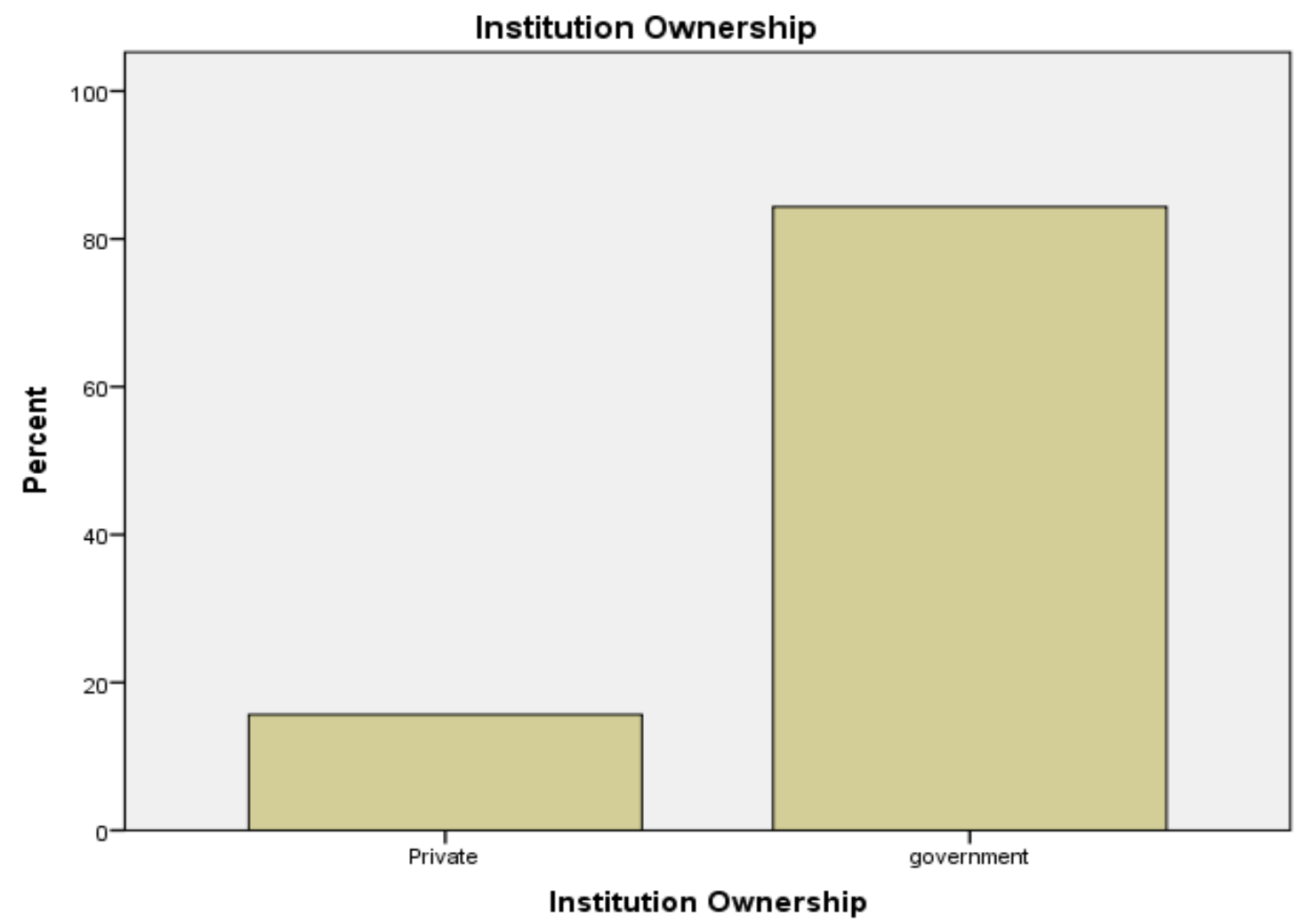

Figure 6: Institution Ownership 
Financial institution will enhance more loans to the needy students

The result of the analysis indicates that nearly $1 / 5$ of the respondents were fairly supportive to the idea of engaging Financial Institution in the students' loans provision while $1 / 4$ of the respondents ranks the idea as good and the rest percentage were evenly distributed among the respondents. This distribution is explained more by the bar chart shown under Figure 7.

Table 7:

FI Enhance more Loans to the needy Students

\begin{tabular}{|l|r|r|r|r|}
\hline & Frequency & Percent & \multicolumn{1}{|c|}{$\begin{array}{c}\text { Valid } \\
\text { Percent }\end{array}$} & $\begin{array}{c}\text { Cumulative } \\
\text { Percent }\end{array}$ \\
\hline Fair & 17 & 20.5 & 20.5 & 62.7 \\
Average & 15 & 18.1 & 18.1 & 42.2 \\
Good & 20 & 24.1 & 24.1 & 24.1 \\
Valid Very & 16 & 19.3 & 19.3 & 81.9 \\
Good & 15 & 18.1 & 18.1 & 100.0 \\
Excellent & 83 & 100.0 & 100.0 & \\
Total & &
\end{tabular}

Source: Survey data (2017)

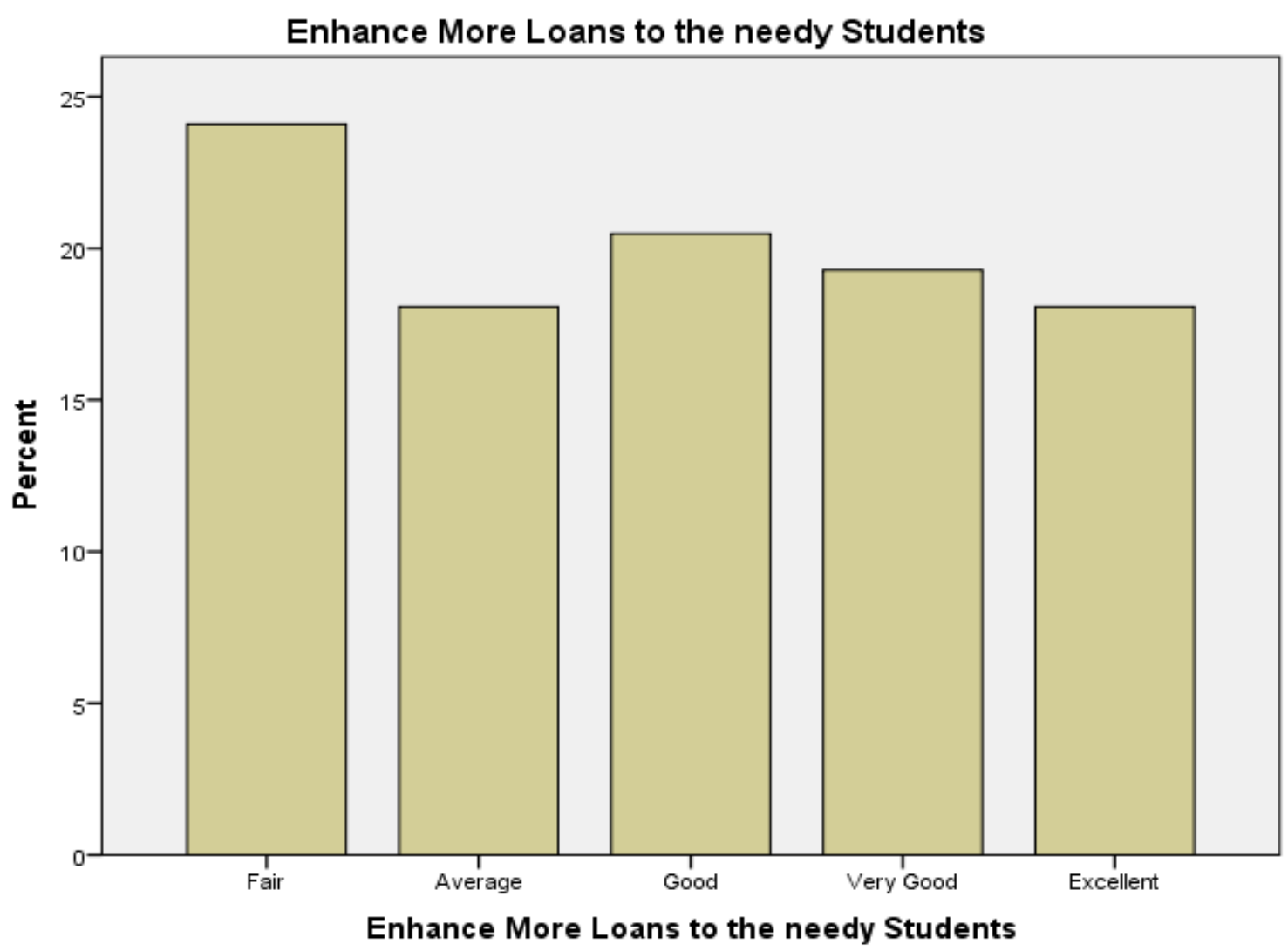

Figure 7: Enhance More Loans to the Needy Students 


\section{University or College to surrender certificates of loan beneficiaries to FI}

More than 1/4 of the respondents from universities or colleges advocate that they are ready to surrender their certificates as collateral to financial institution. $24 \%$ of the respondents accept that to surrender certificates as collateral to financial institution is a good idea, $1 / 5$ of the respondents argue that it is fair. The rest of the percentages were distributed among average responses and Excellent. This result was expected by researcher because students' who are needy are expected to have no other asset to surrender as collateral to the financial institutions. Therefore, the population was fairly represented by the sample. This distribution is explained more by the bar chart shown under Figure 8.

Table 8: University to Surrender Certificates of Loan Beneficiaries to FI

\begin{tabular}{|l|r|r|r|r|}
\hline & Frequency & Percent & $\begin{array}{c}\text { Valid } \\
\text { Percent }\end{array}$ & $\begin{array}{c}\text { Cumulative } \\
\text { Percent }\end{array}$ \\
\hline Fair & 18 & 21.7 & 21.7 & 21.7 \\
Average & 9 & 10.8 & 10.8 & 32.5 \\
Good & 20 & 24.1 & 24.1 & 56.6 \\
Valid Very & 23 & 27.7 & 27.7 & 84.3 \\
Good & 13 & 15.7 & 15.7 & 100.0 \\
Excellent & 83 & 100.0 & 100.0 & \\
Total & & & & \\
\hline
\end{tabular}

Source: Survey data (2017)

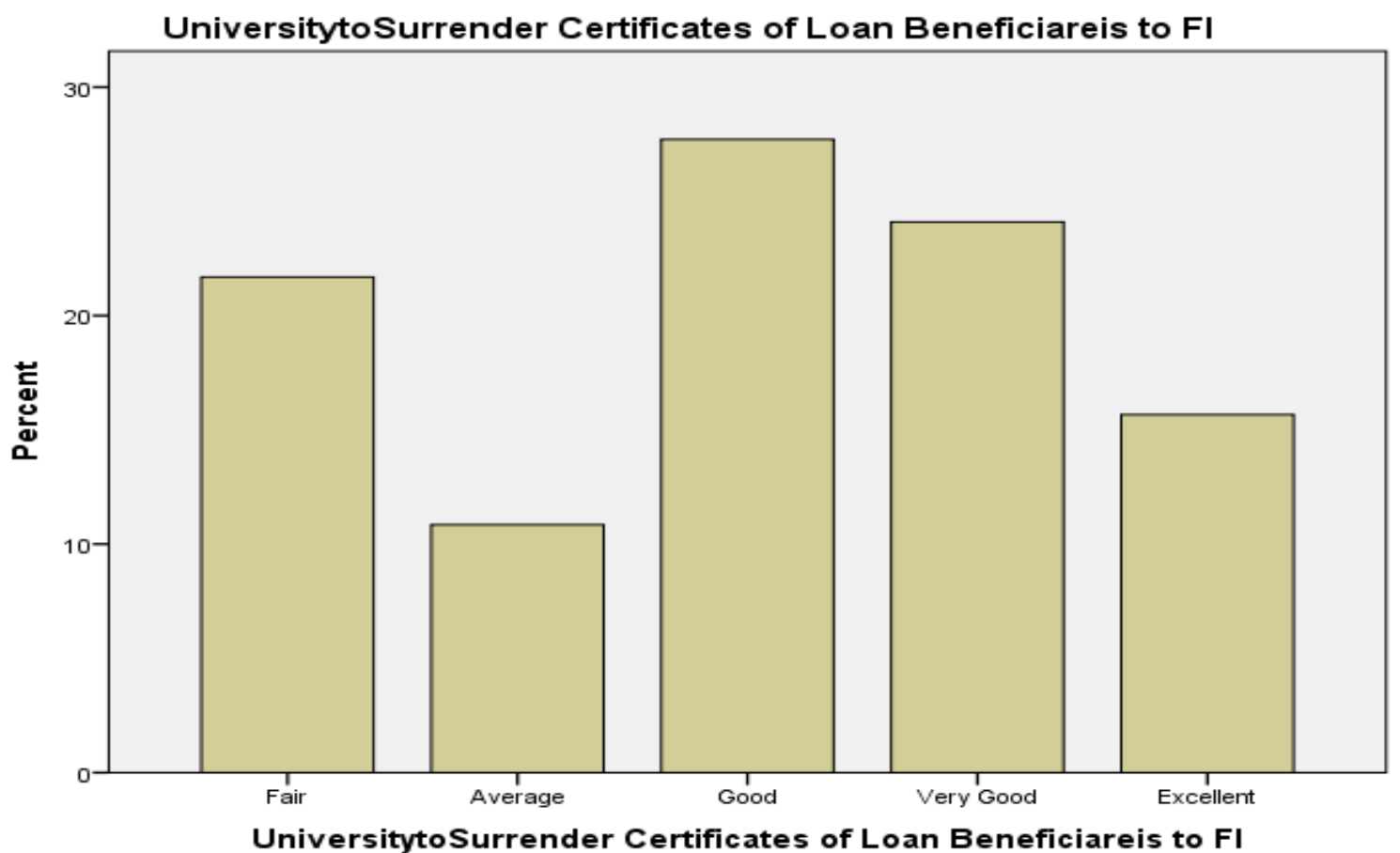

Figure 8: University to Surrender Certificates of Loan Beneficiaries to FI 
FI will be allowed to request for additional securities

A total of 83 respondents were obtained, more than $1 / 3$ of the total respondents suggest that financial institutions should not be allowed to request for additional securities more than the certificates which will be surrendered by the universities/colleges. While only $12 \%$ of the respondents accept the submission of additional securities to the financial institutions. The population was fairly represented, because needy students were expected by the researcher to have no more security to surrender other than their certificates. This distribution is explained more by the bar chart shown under Figure 9.

Table 9: FI will be allowed to request for additional securities

\begin{tabular}{|l|r|r|r|r|}
\hline & Frequency & Percent & $\begin{array}{c}\text { Valid } \\
\text { Percent }\end{array}$ & $\begin{array}{c}\text { Cumulative } \\
\text { Percent }\end{array}$ \\
\hline Fair & 28 & 33.7 & 33.7 & 33.7 \\
Average & 16 & 19.3 & 19.3 & 53.0 \\
Good & 18 & 21.7 & 21.7 & 74.7 \\
Valid Very & 11 & 13.3 & 13.3 & 88.0 \\
Good & 10 & 12.0 & 12.0 & 100.0 \\
Excellent & 83 & 100.0 & 100.0 & \\
Total & & & \\
\hline
\end{tabular}

Source: Survey data (2017)

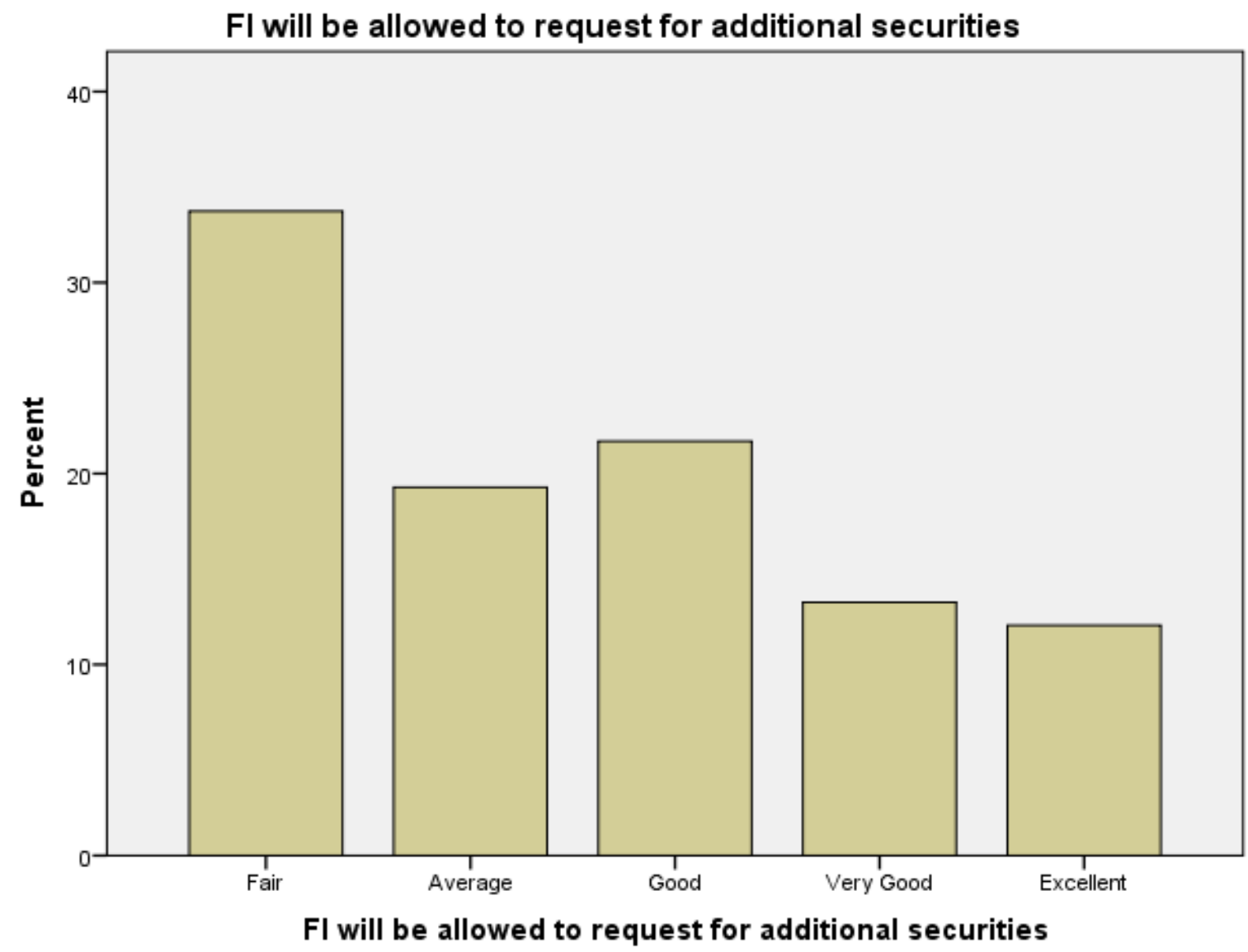

Figure 9: FI will be allowed to request for additional securities 
Is there policy for students to seek loans from FI

More than $60 \%$ of the respondents confirm that there is no policy which allows students to seek students' loans from financial institutions and about $35 \%$ accept that there is such policy. The sample represents fairly the population, the researcher expected to find this result because students' finances through financial institutions is a new phenomenon in the country therefore it is expected that most universities/ colleges have not yet incorporated in their policies. Also most universities are expected to consider only their core business in their policies, which includes education, research and consultancy, other issues concerning students' finances remain solely personal to student him or herself. This distribution is explained more by the bar chart shown under Figure 10.

Table 10: Is there Policy Considering Students To Seek Loans

\begin{tabular}{|c|c|c|c|c|c|}
\hline & & Frequency & Percent & $\begin{array}{c}\text { Valid } \\
\text { Percent }\end{array}$ & $\begin{array}{c}\text { Cumulative } \\
\text { Percent }\end{array}$ \\
\hline \multirow{3}{*}{ Valid } & Yes & 29 & 34.9 & 34.9 & 34.9 \\
\hline & No & 54 & 65.1 & 65.1 & 100.0 \\
\hline & Total & 83 & 100.0 & 100.0 & \\
\hline
\end{tabular}

Source: Survey data (2017)

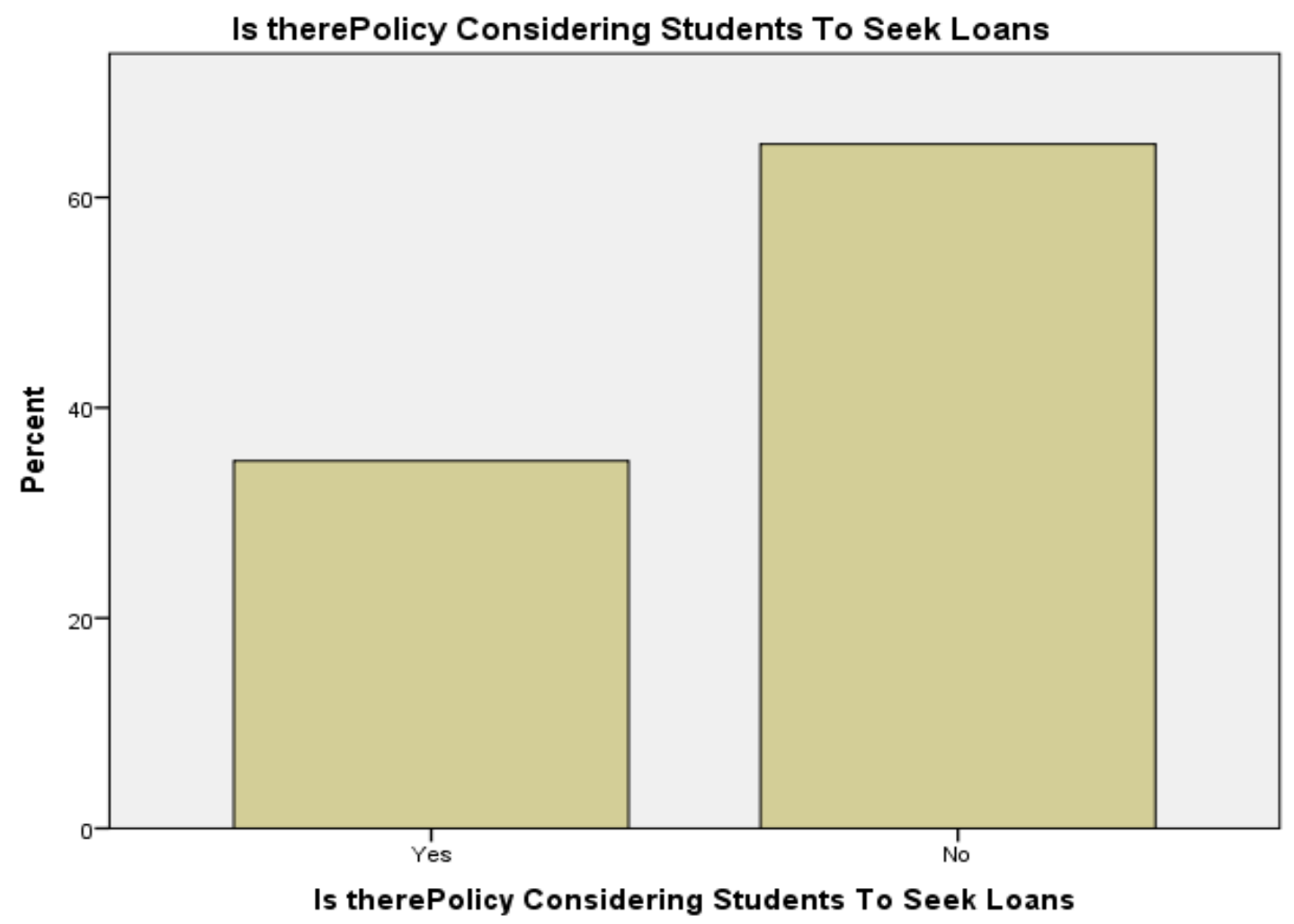

Figure 10: Is there Policy Considering Students to Seek Loans 
FI can use beneficiaries' certificates as collateral

More than 3/4 of the respondents from universities or college advocate that financial institutions can use certificates as collateral when giving students' loans. While $1 / 4$ of the respondents reject the use of certificates as collateral by the financial institutions. This result was expected by researcher because students' who are needy are expected to have no other asset to surrender as collateral to the financial institutions. Therefore, the population was fairly represented by the sample. This distribution is explained more by the bar chart shown under Figure 11.

Table 11: FI Can Use Beneficiaries' Certificate as Collateral

\begin{tabular}{|c|r|r|r|r|}
\hline & Frequency & Percent & $\begin{array}{c}\text { Valid } \\
\text { Percent }\end{array}$ & $\begin{array}{c}\text { Cumulative } \\
\text { Percent }\end{array}$ \\
\hline Valid No & 61 & 73.5 & 73.5 & 73.5 \\
Total & 22 & 26.5 & 26.5 & 100.0 \\
\hline
\end{tabular}

Source: Survey data (2017)

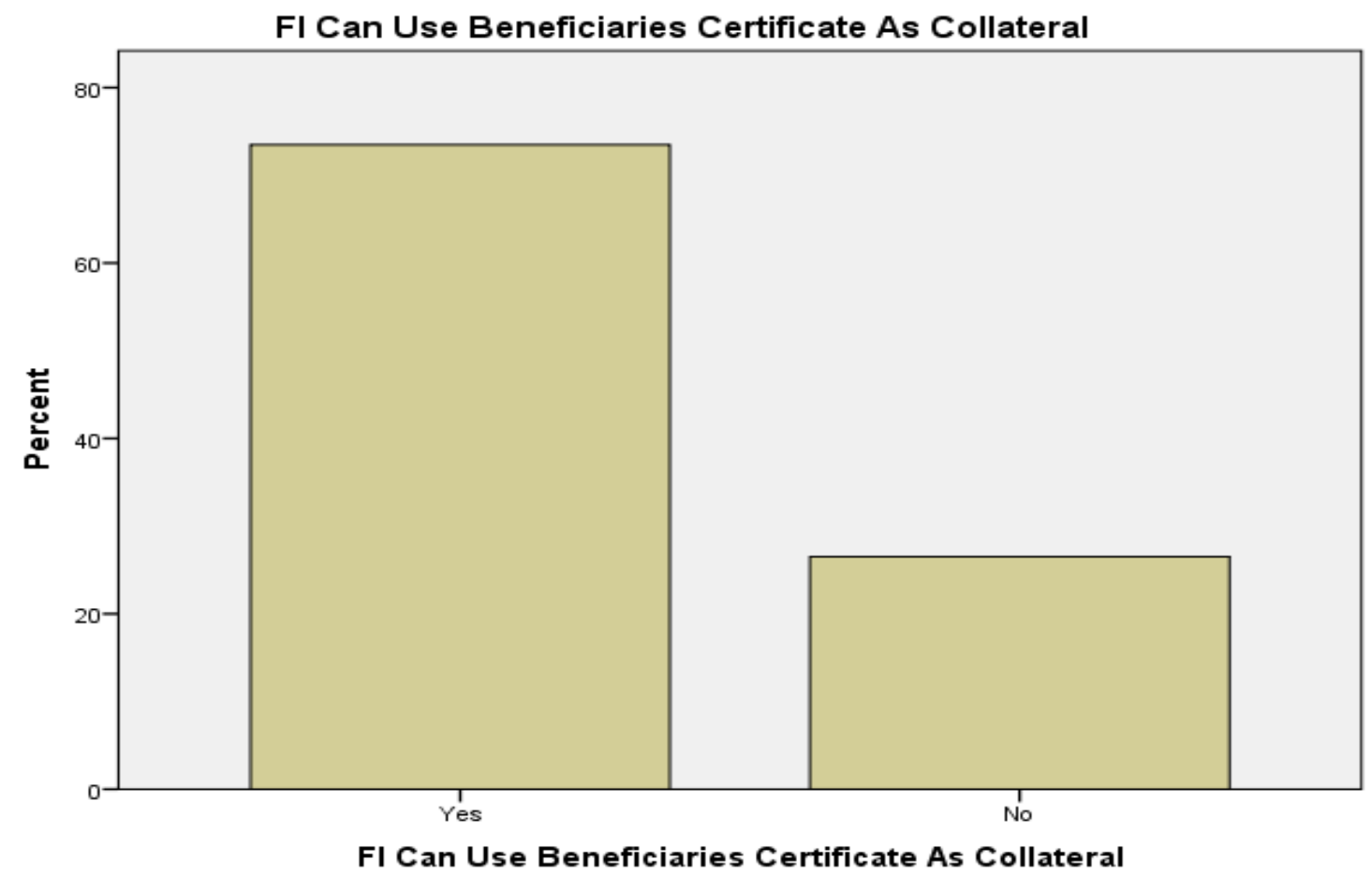

Figure 11: FI can Use Beneficiaries Certificate as Collateral 


\section{Data collection Methods}

In this study, quantitative data were obtained from both primary and secondary source, Primary data were gathered through the use of structured questionnaires and interview. Structured questionnaires (Appendix 1) were distributed to the respondents from the selected universities and financial institutions. In the primary source the researcher obtained information concerning the terms and conditions for students' loans provision if any, the policy and the current portfolio available in the students' loans provision, what is the current interest rate on loan provision, what is the coverage for students' loans provision example program to be considered if any, and the gender parity consideration if any. Also, the researcher obtained information on how respondents from universities perceived the engagement of financial institution to partner with HESLB in the students' loan provision, what are terms and conditions they think are favourable for loans provision by financial institutions and how they see the consideration for the financial institutions in using beneficiary's certificates as collateral.

Interview on the other hand was conducted with 26 members of management in both the selected financial institutions and the universities. The researcher obtained information concerning the actual implementations of the intended idea i.e. the respondents were asked on how were ready to start implementing the policy on students' loans provision, do they have the policy in operation concerning students' loans provision.

Secondary data was based on the information concerning the ownership, tenure of the financial institution or university were obtained by reviewing the policy document of organization or university with the focus to the students' loans provision. Strategic plan was also reviewed to understand the future prospects of the financial institutions or universities in the students' loans provisions as well as the vision and mission. Loan allocation and repayment manual were reviewed in the financial institution for the researcher to understand the terms and condition for provisions and repayment of the students' loans or other loans managed by the financial institutions.

\section{Data Analysis}

Analysis of the collected data were made using the Software Package for Statistical Science (SPSS) and the Content analysis. Results of the analysis from SPSS were presented and summarised in the frequency distribution table and the bar charts were also used to explain the results. Documents analysis were also conducted in which documents were interpreted to give meaning according to the subject, also documents were incorporated into coding content to give meaning before being presented into a tabular form. Output for both SPSS and Content analysis was handled with greater flexibility. 


\section{Findings}

\subsection{Survey Results}

In guiding this survey questionnaires were used to assess the feasibility of engaging financial institutions in financing higher education. These questionnaires were as mentioned below:

(i) Is there any policy consideration in the financial institutions regarding students' loans provision?

(ii) Are the higher education students ready to be financed by the financial institutions?

(iii) Are the financial institutions ready to engage in students' loans provision?

\subsubsection{To determine whether there is policy consideration for students' loans provision by financial institutions}

Data were collected from the selected financial institutions to answer properly the questions concerning this objective. The results of the analysis indicate that more than $80 \%$ of the respondents indicates that financial institutions do not have any policy concerning students' loans provision, while only $14 \%$ of the respondents indicates the presence of the policy considerations for students' loans provision in the financial institution.

Interview made to Tanzania Postal Bank (TPB) indicates that TPB has partnered with Public Service Pension Fund (PSPF) to issue education loans to its members. Most of the loans at TPB are purely issued to support, operations or development of businesses or projects and others to meet personal pressing needs. They don't have specific policy for students' loans provision. Interview results from Tanzania Women Bank (TWB) and the National Bank of Commerce (NBC) also indicates that there is no policy considerations for students' loans provision instead available policy is for financing of working capital and personal loans for salaried workers, in which they have different terms and conditions from that of HESLB.

Results of the interview made to various universities/ colleges (UDSM, CBE, and DUCE) regarding policy consideration for students' loans provision by financial institutions indicates that financial institutions in the country doesn't have any policy to guide provision of students' loans.

Therefore, there is no policy consideration for students' loans provision by financial institutions

\subsubsection{To examine the readiness of the students in the higher learning institutions to be financed by financial institutions}

Data were collected from the selected universities or colleges to answer properly the questions concerning this objective. The results of the analysis indicate that nearly $1 / 5$ of the respondents rank as fair the concept that engagement of the financial institutions will enhance more students' loans to the needy students 
while $1 / 4$ of the respondents ranks the concept as good and the rest percentage were evenly distributed among the respondents.

Also the result indicates that more than $1 / 4$ of the respondents from universities or college advocate that they are ready to surrender their certificates as collateral to financial institution. $24 \%$ of the respondents accept that to surrender certificates as collateral to financial institution is a good idea, $1 / 5$ of the respondents argue that it is fair.

Results indicate that more than 3/4 of the respondents from universities/college advocate that financial institutions can use certificates as collateral when giving students' loans. While $1 / 4$ of the respondents reject the use of certificates as collateral by the financial institutions.

Also the interview results from UDSM further indicates even though there is no policy which allows students to borrow from financial institutions still students have the believe that engagement of financial institutions will bring solutions to the higher education students' financing problems.

Therefore, students in the higher learning institutions are ready to be financed by financial institutions.

\subsubsection{To investigate the readiness of the financial institutions to provide loans to students of the higher learning institutions.}

The results from the interview indicates that some financial institutions are willing to participate in supporting students on the concessional rate below the rate charged by Banks commercially, on the agreement that the Bank will hold the original academic transcript and original certificates as collateral together with the Government guarantee on the difference among the rates.

Results from the interview made at the Tanzania Women Bank (TWB) indicates that HESLB to continue giving loans to students and only the difference has to be covered by the financial institutions, this shows that financial institution is ready to engage partially in students' loans provision.

Further interview at TPB indicates that financial institutions are not sure of the repayment because of the unemployment problems facing the country as well as the Government uncertainties in loan repayment. Also, NBC is worrying about dropout in case the Government won't guarantee.

Furthermore, results of the interview from Bank M. indicates that even though there is no specific lending policy for students, the bank' credit policy allows lending to education sector up to $15 \%$ of the bank' portfolio. The interview also reveals that Concessional rate may be availed depending on negotiation between lender and borrowers. Key factors involved are: amount of loan, market conditions such as interest rate, exchange rate, inflation, competition from other players this indicates that negotiation with the Government on concessional rate for students' loans will be possible because they already have the policy.

Therefore, financial institutions are not ready to provide loans to students of the higher learning institutions. 


\section{Conclusions}

Engagement of financial institution in the students' loans provision will reduce the Government burden and help in financing more needy students, who otherwise could go without loans due to the limited Government budget. Therefore, this study concluded that:

Most of the financial institutions do not have the policy for students' loans provision, this have been explained by more than $80 \%$ financial institutions which do not have the policy for students' loans consideration.

It was concluded that most of the financial institutions have the shared ownership between the government and private, this will result into difficulties for the government to implement its policy, because the government doesn't have control at $100 \%$. Financial institutions will have to implement their objectives first. The Government cannot implement the policy for students' lending on its own, it will need to work with the financial institutions in line to their regulations.

It is concluded that most universities or college do not have policies which allow students to seek students' loans from financial institutions because it is a new phenomenon in the country.

It was also concluded that students' in the higher learning institutions are ready to surrender their certificates to the financial institutions as collateral for their students' loans hence they are ready to be financed by financial institutions. But they don't want to be asked for additional security such as houses etc. because they said they don't have any other security to support them.

It was also concluded that by engaging financial institutions in students' loan provision it is sure that only the needy students will apply for loan and not like the way application is mixed-up at HESLB between the needy and not needy, which call for the need to means tests.

It was concluded that financial institution were suggesting to have an opportunity to ask for more security, because they said after graduation students can leave their certificates for a long time without repaying their loan due to the unemployment and underemployment problem facing the country. In which this will be a risk to the financial institutions as they will be using other depositors' fund to lend to students of higher learning institutions.

It was concluded that most of the financial institutions doesn't have confidence on how repayment could be, as they are not sure of how the government guarantee will cover the risk associated with the loan given hence they are not ready to engage in students' loans provision.

Through engagement of financial institutions in students' loans provision, it is expected that only genuine students' loans applicants who are needy will remain in this loan processing brackets others will drop because of the procedures. Those students' applicants who are not needy will be expected to drop instead they will use their own fund for higher education

It was finally concluded that submission of certificates to financial institutions will call for non-demand of certificates in some of the employers which may results into production of fake certificates if the government is not that keen in checking the authentications of the certificates through universities. 


\section{Recommendations}

According to the findings and conclusions it is recommended that:

Financial institutions in Tanzania to establish the students' loan provision policy to be included in their operation policy as one of their obligations. This policy should spell out specifically on how to handle repayments in case of dropouts due to discontinuous, abscondments, postponements. Aptitude test should be made before loan provision etc.

Financial institutions should be advised to include the clause on gender parity considerations in their loans provision policy, because women and disabled has to be taken care due to a long marginalization which was existing in the country, they need support to catch up with the growing economy.

To educate all the students' loan beneficiaries to understand the current financial situation of the Government and the need for alternative financing to ensure sustainability of the students' loans scheme. Also, students have to be educated on the importance of repaying their loans timely to the financial institution after grace period in order to recover the certificates handled to the financial institutions as collateral.

Universities or colleges to include policy which allows students to seek for alternative funding from other sources other than HESLB to finance their education example seeking loans from Commercial Banks.

The Government to assure the financial institutions on the safety of their loan provided to students by depositing a substantial amount of money as a guarantee to ensure the readiness of financial institution in students' loans provisions also the Government should increase employment opportunities for easy implementation especially in assurance of repayment to the financial institutions against the students' loans given out.

It is recommended that due to repayment problems experienced at HESLB it is better to engage financial institutions to partner in students' loans provision because, financial institutions are more experienced in loan provision, so it is easy for them to make follow up on repayment. However, financing of the higher education by financial institutions is very difficult, because using certificates as collateral is very risk due to the possibility of having feck certificates.

HESLB should make arrangement with the Ministry of Education Science and Technology (MoEST), the Treasury and the Planning Commission to discuss on how to curtion the difference in interest rate between what will be charged by the financial institutions and the concessional rate. The Government to give a confidence to the financial institution as a main guarantor for students' loans given, because giving loans is not a complex process as the repayment process.

More researches to be conducted on issues of the students' loans finances due to increased challenges brought about by the increased demand for higher education coupled with inability of the Government to fully fund the higher education

HESLB to organize a meeting with all the financial institutions in the country, in which presentations will be made by HESLB on issues concerning the need for students' loans support by financial institutions, the benefits, the challenges and the way forward. Financial institutions should be educated on the inclusion of 
the insurance policy regarding all students' loans given so that to help recovery of all loans in case of students' death.

\section{Acknowledgement}

My special thanks should go to Mr. Asangye Bangu (The then Director Planning, Research and ICT), for his guidance and material contribution towards accomplishment of this work. Mr. Chakaza Cosmas, Mr. Venance Ntiyalundura, Ms Rose Marwa and Ms Mariam Mshana (My co-workers) deserve special thanks for their corporation especially during data collection. Also, social security fund schemes, PPF and PSPF need special mention for the material contribution during the interview. Finally, I should also thank commercial banks which were visited TPB, NBC, TWB and BANK $M$ and various Higher learning institutions for proving me with valuable information through filling of questionnaires.

\section{References}

Bank of Tanzania (2015). List of registered financial institutions, BOT. Retrieved from http://www.bot-tz.org/Banking Supervision/ Registered Financial Inst.asp.

Barr, N., (2009). Financing higher education lessons from economic theory and reform in England; A special issue of Higher education in Europe, (34)2, pp. 201-210.

Chapman, B. \& Mathias S. (2011). Student Loan Reforms for German Higher Education: Financing Tuition Fees, Ruhr Economic Papers, No.244.

HESLB (2015a). Report on Local Undergraduate and local Postgraduate Applications and Allocations, HESLB. Retrieved from the Loan Management System (LMS), on 10 June, 2015.

HESLB (2015b). Report on Accepted and Rejected students' after Means Testing, HESLB. Retrieved from the Loan Allocation Module, on 10 th July, 2015.

HESLB (2004), Act number 9 of 2004 CAP 178, Dar es salaam, Higher Education Students Loans Board.

HESLB (2017), Published guidelines and Criteria for granting loans in the academic year 2016/2017, Dar es salaam, Higher Education Students Loans Board.

Nyahende V.R. (2013). The Success of Students' Loans in Financing Higher Education in Tanzania. The Journal of Higher Education Studies, 3(3), pp 47 - 61. Doi: http://dx.doi.org/10.5539/hes.v3n3p47

Saunders, M., Lewis, P., \& Thornhill, A. (2007). Research methods for Business students, Fouth edition. New York: Prentice Hall.

Social Security Regulatory Authority (2015). The social security schemes in Tanzania, SSRA. Retrieved from http://www.ssra.go.tz on 15th August, 2015.

Tanzania Commission for Universities (2015). The list of higher learning Institutions in Tanzania based on ownership, TCU. Retrieved from www.http://tcu.go.tz/Institutions on 15 th August, 2015.

URT (2005); Review of Financial Sustainability in Financing Higher Education in Tanzania MSTHE, Dar es salaam, Government Printing Press.

Ziderman, A. (2004). Policy options for student loans schemes: Lessons from five Asian case studies. UNESCO Bangkok Publishers. Bangkok, Thailand. 


\section{QUESTIONNAIRES}

APPENDIX 1

\section{Questionnaire for Financial institutions only}

The main aim of this questionnaire is to get information which will help the Higher Education Students' Loans Board (HESLB) in identifying and subsequent engagement of the Financial Institution which can be supportive in the Higher Education Financing. The questionnaire specifically covers the selected financial institutions and the selected Universities/Colleges in Dar es salaam in which Management, key Staff in a specific area, and students' organizations will be required to fill in the questionnaires. The results of this Survey will be used solely by HESLB in identifying the financial institutions which will fit the purpose. You are requested to complete this questionnaire to enable timely accomplishment of the survey. We would appreciate for your prompt response.

SECTION A: General Information, Please fill in the blank spaces provided/ please circle

(1) Name of the Financial Institution

(2) What is the ownership of your Institution?

(a) $100 \%$ Private (b) $100 \%$ Government (c) Shared between private and Government

SECTION B: Consideration for Higher Education Students' Loans Issuance

(1) Is there any Policy for Higher Education Students' loans Consideration? (Please Circle)

$\begin{array}{lll}\text { (a) Yes } & \text { (b) No }\end{array}$

If no, Why

(2) What are the terms and conditions of the Higher Education students' loans issuance? (Mention at least five conditions)

(3) What is the Current portifolio for students' loans?...............................................is there any plan to increase the portfolio?................................(Yes/No)

(4) (a) What is the Coverage of the Higher education students' loans issuance,(What kind of applicants/ Study program are considered)

(b) Is there any considerations for Gender Parity ( any consideration for a particular group of people) (Yes/ No)

SECTION C: Modus Operandi for Repayments

(1) What is the conditions for Loans Repayment, (Mention at least five conditions) 
(2) (a) What is the current interest rates charged?

(b) What is time framework

(c) Is there any grace period for repayment? (Yes / No )

(d) What is the opinion in handling the difference in case there is no any concessional rate?

\section{Questionnaire for Higher Learning Institutions only}

The main aim of this questionnaire is to get information which will help the Higher Education Students' Loans Board (HESLB) in identifying and subsequent engagement of the Financial Institution which can be supportive in the Higher Education Financing. The questionnaire specifically covers the selected financial institutions and the selected Universities/Colleges in Dar es salaam in which Management, key Staff in a specific area, and students' organizations will be required to fill in the questionnaires. The results of this Survey will be used solely by HESLB in identifying the financial institutions which will fit the purpose. You are requested to complete this questionnaire to enable timely accomplishment of the survey. We would appreciate for your prompt response.

SECTION A: General Information, Please fill in the blank spaces provided/ please circle

(1) Name of the University/College.

(2) What is the ownership of your Institution?
(a) $100 \%$ Private
(b) $100 \%$ Government

SECTION B: Consideration for Higher Education Students' Loans Issuance by the Financial Institutions (Please Circle)

1=Fair, 2=Average, 3=Good, 4=Very good, 5=Excellent

(1)Financial institution will enhance more students' loans to the needy students

$\begin{array}{llllllll}\text { Not at all } & 1 & 2 & 3 & 4 & 5 & \text { To a great }\end{array}$ extend.

(2) Universities/ Colleges will surrender the certificates of the students' loans beneficiaries, who benefited from the Financial Institutions as collateral to lenders

$\begin{array}{lllllll}\text { Not at all } & 1 & 2 & 3 & 4 & 5 & \text { To a great }\end{array}$ extend

(3) Financial Institutions will be allowed to request for additional securities on top of the beneficiaries Certificates.

$\begin{array}{llllllll}\text { Not at all } & 1 & 2 & 3 & 4 & 5 & \text { To a great }\end{array}$ extent. 


\section{SECTION C: Others (Please fill the Blanks)}

(1) Is there any Policy (within the university/ College) considering students to seek loans from Financial Institutions? (Please Circle)
(a) Yes
(b) No

If no, Why

(2) What do you think should be the terms and conditions of the Higher Education students loans issuance by the financial Institutions? (Mention at least five conditions)

(3) (a) What do you suggest to be the coverage of the Higher education students' loans issuance by the financial institutions? (What kind of applicants/ Study program are considered?)

(b) Should there be the considerations for Gender Parity ( any consideration for a particular group of people). (Yes/ No).

(c) Financial Institutions can use beneficiaries' certificates as one of the collateral instruments for Higher education students' loans. ( Yes / No ).

If No, give explanations. 